\title{
Dukor’s Theistic Humanism, Panacea to Globalization
}

\author{
Mark Omorovie Ikeke \\ Department of Religious Studies and Philosophy, Delta State University, Abraka, Nigeria \\ Email: Ikeke7@yahoo.com
}

Received November $30^{\text {th }}$, 2012; revised December $29^{\text {th }}$, 2012; accepted January $15^{\text {th }}, 2013$

\begin{abstract}
Globalization is now a force that must be reckoned with. Globalization has both good benefits and negative effects. This paper examines the benefits and dangers of globalization. The paper uses a critical analytic method to examine the theistic humanistic philosophy of Maduabuchi Dukor and its contribution in this time of globalization. The African idea that man can accomplish his highest rooted in theistic values makes it different from every other form of humanism. The paper concludes and argues that the solution to the excesses of globalization is theistic humanism.
\end{abstract}

Keywords: Dukor; Theism; Humanism; Globalization; Africa

\section{Introduction}

Dukor (2007) writes:

Across the length and breadth of Asian and African communities there is that conscious and inexorable desire by the people to preserve their aboriginal cultures, retain their identity and live the authentic life. The authentic question is not only a cultural question but also a development question. If that is the case, we have to review the relations between the triad problem of authenticity, culture and development.

The above quotation provides the basis for this paper. It should be noted that most postcolonial societies have rich and genuine cultural practices and values that need to be preserved and promoted. The tragic reality is that some if not most of these values have been trampled upon and denigrated by colonialism and they are now being continuously destroyed by Western global capitalist market values. In the midst of the predicaments that postcolonial societies are passing through at this time of globalization, we need philosophies that affirm life and justice to combat the situation. Many philosophies of African identity proposed by Contemporary African philosophers can help in this regard. These philosophies include: Negritude by Leopold Senghor, Philosophical Consciencism by Kwame Nkrumah, African Humanism by Kenneth Kaunda, Ujamaa by Julius Nyerere, and Maduabuchi Dukor's Theistic Humanism.

\section{Dukor's Theistic Humanism}

In Dukor theistic humanism is the African and philosophic principle that encapsulates their beliefs about man, God, and the universe. His idea of theistic humanism is clearly spelt out in his book, Theistic Humanism of African Philosophy: The Great Debate on Substance and Method of Philosophy. Theistic humanism informs and grounds African metaphysics and epistemology. Africans are deeply spiritual people and believe that God created the universe and all that is it including human persons. Africans generally are not atheistic. There is a personal God and his divine spirit is the life force that permeates all things in the universe.
It is important to note that his theistic humanism is discussed often in the light of globalization. In explaining the trends which globalization follows in history, he listed out five stages which he begins with animistic globalization which is African in nature. According to him the humanistic African philosophy which gives precedence to the activities of human is the central point which globalization emanate from. He coined the animistic globalization from the ancient African practice of using the sky and the star to define universal scope of contribution. Dukor analogy of the animistic globalization was that of his grandfather, Gbusuizu Dukor who could utilize the strength of the rationale in building a well and form economical structure which is global in its intrinsic nature. Characterized as limited because it is geographically based on the atmosphere which can be perceived by Africans.

However, globalization is a variance with the humanistic African culture with a cultural horizon. Globalization is a philosophy that is all encompassing of all tribes and nations. Dukor on careful examination of the changes the global village from the animistic to the next stage which is that of the evolution rise of man i.e. negroid, causasoid and mongoloid. This phase is that of empires and slavery. Showing a trend in globalization when Africans were sold to Europe to work and labour freely. European exploitation is revealed as African barely understanding the trend in globalization that where mainly enslaving. On disguise of cultural inter-relation, the third phase which is that of colonialism that partitioned African continent into the selfish hands of the European. Championed under the guise of western education and western religion such as Christianity, colonialism took over the African soil. Such philosophy that is exploitative and dehumanizing.

This was immediately followed by the fourth stage which is the importation of western technologies and scientific advancement aimed at making African to be totally dependent on these western technologies which is another stronger form of neo-colonialism. Finally, the last trend of globalization is that which integrates people into the world through modern tools of communication and the united nation such as e-mails, telecommunication, etc.

Upon careful analysis of these stages, Dukor concludes that 
the globalization today is different from that of his grandfather which he called animistic globalization because the animistic globalization looks into the betterment of the life of the few size population, this form is characterized by the global spirit which ensures that man's interest is protected by the gods through the activities of men. On the other hand, he sees globalization, its technological provision and all its vices as another form of western colonialism. It is that African theistic humanistic value from which globalization arose that can also provide it a solution. Let us pursue further how to understand globalization that theistic humanism can be a solution to.

\section{What Is Globalization?}

Globalization is a contested concept. It is a concept loaded with multiple and multi-variant meanings. There are probably as many definitions of globalization as you have scholars of globalization. Its benefits and evils are fought over. Depending on your viewpoint it can have a remote or proximate origin.

Globalization has to do with the entire globe or world. It is a worldwide phenomenon. In simple terms, it is the coming together of all the people and places in the world through all the means of mass communication and transportation. It is the entire processes involved in the world becoming a global village. Frontiers and boarders are shrinking

Though right from the dawn of human history it can be argued that globalization has started; in its more technical sense, globalization can immediately be said to "having historical take-off point after the collapsing into a single ideological system-capitalism” (Umo, 2007: p. 658).

There are many definitions or understanding of globalization. Some are presented below:

- "Globalization refers to the growing integration of the world economies. It is the worldwide intermingling of culture, politics, economics, technology, etc. (Umo, 2007: p. 658).

- "Globalization is multi-dimensional, affecting all aspects of life-economic, cultural, environmental and social-as well as relations between government and nations of the five continents (Daouas, 2001).

- "This refers to the process by which the world is said to be transformed into a single global system. It became an issue of great significance in the 1990s. Aspect of what is now called globalization was first seriously discussed by sociologists during the 1960s and 1970s (Abecrombie, Hill, \& Turner, 2000: p. 153).

- Globalization is primarily based on the elimination of technical obstacles, rather than economic ones. It is the abolition of distance and time ... The starting point was the enormous acceleration and global spread of good transport (Habsbawn, 2000: pp. 62-63).

- In 1960, MCLUHAN introduced into the analysis of culture and the mass media the phase "the global village", in order to describe how, in his view, the world was shrinking as a result of new technologies of communication. In the same period, changes in the global economy, notably the growth of multinational companies (MNCs), the expansion of international trade, the international division of labour, prompted the development of the world system theory as a model of the global economy, in current discussions, globalization has three dimensions or manifestations: Economic, cultural and political. (Abecrombie, Hill, \& Turner, 2000: p.
153).

According to Abercrombie, Hill, and Turner (2000), the economic dimension refers to "the expansion and transformation of capitalism into an integrated global economy. The most important change has been the expansion of world financial markets. Globalization of culture is said to be the result of rise of mass tourism, increased migration of people between societies, the commercialization of cultural products and the global spread of an ideology of consumerism, which has the effect of replacing or supplementing more localized cultures. In the political sphere, globalization has been the rise of international agencies, including the World Bank, the International Monetary Fund and the World Trade Organization, which regulates the global economy and, therefore, set limits on the freedom of the nation states.

Globalization has certainly made tremendous impact both positive and negative on almost every nation and society on planet earth. Globalization is so vast a topic that it is difficult to do full justice to it in a short paper like this. There are scores of resources including books and journal articles on globalization. Though there are perceived benefits of globalization, most of the books and journal articles dwell more on the devastating and negative effects of globalization. This of course shows that it has more disadvantages than advantage. We now examine these impacts.

\section{Positive Impacts of Globalization}

Globalization is a very controversial phenomenon and it has a litany of discontents. For some people, globalization as a "process is unstoppable; therefore nations have to deal with it one way or another. What are the benefits of globalization, if any? Globalization has both advantages and disadvantages. Umo (2007: p. 676) states some of the advantages of globalization as:

The (actual/potential) benefits of globalization especially to African countries include the following: 1) offering a wide regional and global market access to economic goods and services produced within each country; 2) the potentials for increased trade volume for viable African economies; 3) greater availability of rare global goods/ service, especially, in science and technology; 4) enhancement of product quality; 5) efficiency gains in product; 6) emergence of regionalism; 7) diversification of sources of development finance.

In the next section, we will deal with the negative impacts of globalization. I note here that no matter how devastating the impact of globalization, it seems to be a force that is ravaging through the globe. We have no option but to confront it. One of the ways to confront it is to equally tap the very resources of globalization and use them to our good. On this Jimmy O. Chijioke writes that we can evolve global mechanism to track and report corrupt and unethical practices in public services. These mechanisms include:

The United Nation's Global Programme Against Corruption, designed by the Centre for International Crime Prevention-CICP-in collaboration with, the UN Inter-Regional Crime and Justice Research Institute-UNICRI. The Programme comprises three main components-Action Research (Learning by Doing), Technical Coopera- 
tion, and Monitoring and Evaluation. Part of the objectives of the programme is the provision of anti-corruption tools to raise the probability of detection and the cost of participation in corruption activities, thereby increasing the risk of involvement. United Nations Code of Conduct for Law Enforcement Officials (1996); United Nations Development against corruption and Bribery in International Commercial Transactions (1996); the Parlemo, Italy, 2000: Manual on Practical Measures Against Corruption (1977). The Manual contained the following Measures amongst others (Chijoke, 2007: p. 37).

The events of the coming of western education, international humanitarian intervention of the United Nations and other world bodies in failed states and famine ravaged nations to provide food and other resources are all aspects of globalization. It will be theoretically/practically wrong to affirm that globalization has not brought any benefit at all. H. A. Ekiyor writes: "Globalization has increased interconnectivity, communication, transaction and trade among various nations of the world." (Ekiyor, 2007: pp. 37-39).

\section{The Negative Impact of Globalization}

According to Nwakaeze and Odua (2007: p. 8), Globalization is founded on such philosophies as Materialism, Monism, Darwinism, Naturalism, Consumerism. For them, materialism "reduces man to a biological and sentient animal, hence denies the reality of the spiritual. "Materialism has ravaged every institution, religion and cultural ones." Materialism is propelled by a morality of no morality and so ultimately human rights and other moral values have no foundations. On Darwinism they write that it postulates the survival of the fittest. This being the case it has no respect for the weak and feeble of society that the historical religious traditions cherishes and they need to be catered for through social welfare.

- Naturalism identifies man with nature and very often disregards the spiritual. It falls into the same problem of materialism. Consumerism places undue belief in materialistic values of pleasure and consumption. The authors just mentioned are right when they argue: "Globalization is not concerned so much with the individual, ethics, and the spiritual; it seems to have rhymed with Epicurean belief that he had liberated man from the fear of man or God, the only concern in their profits, hence they can use any measure to get profit” (Nwakaeze \& Odua, 2007: p. 8). It creates structural interdependence making one system or entity depends on the other, for better or worse (Umo, 2007: p. 658). The disadvantages associated with globalization include 1) financial and economic risks; 2) rising inequality between nations, regions and individuals; 3) negative impact of economic reforms, especially on exchange rate depreciation; 4) generating growing external indebtedness; 5) increase in economic deprivation; 6) constraints on domestic economic policy making; 7) technological laggardness, especially, of a digital divide variety; and 8) the brain drain constituting a dead weight loss to the continent and their affected countries.” (Umo, 2007: p. 658).

It would seem that the most prominent aspect of globalization and the most noticeable is the economic aspect or what is called economic globalization. This economic dimension constitutes the "core driving forces in the globalization process."
Umo, 2007) argues that the economic underpinning of globalization is threefold. They are: "the collapse of communism and the subsequent consolidation of liberal capitalism as the dominant economic system," "the liberal cross-border flow of trade, finance and labour," "the real time exchange of technology and information system across the entire globe.

It is in the economic dimension that the impact of globalization is so devastating. The driving force behind global economic markets is of course profit. In capitalism, profit comes before people. Capitalism is Machiavellian when it comes to making profits. All is well as far as markets are profitable. Globalization has no respect for indigenous ecological values that have helped indigenous people to navigate through the sorrows and crises of life. International multinational companied can go into indigenous land like those in the Amazon and Congo in search for mineral resources. Forest and cultural heritage have been destroyed in the quest for mineral resources. International multinational corporations can bribe their way through to ensure they get what they desire. For western capitalist prospecting for mineral resources and where to establish their factories for cheap labour all lands are to be leveled and developed. There is no place for underdeveloped land. In the African indigenous traditions, all lands don't have to be developed. There is a place for leaving land for recreational and religious purposes. Banjo (2000: p. 19) is very critical of Western capitalism when he writes:

These transitional bodies are wicked machines of the imperialists, which completely have their pedigrees in the ideological frameworks of the West and its monopolistic views of what the world should look like.

Globalization essentially promotes a Eurocentric and Western liberal capitalist market agenda. Odia (2006: p. 280) is right when he argues:

Western society is capitalist oriented, and technology employs capitalist techniques. These techniques are imported to technologically backward countries like those in Africa and they aggravate the problems of the latter. In addition, it is being argued that the price mechanism, determined by the west is the newest form of slavery. This makes raw materials and agricultural products very cheap compared to the industrial products from the west.

Many authors are right when they argue that: Globalization essentially has Eurocentric bias and basis. In order words, it is the celebration of European values and ideas of development that are often found to be antithetical to African needs. The globalization of European and American values has often played a denigrating role in the comprehension of African realities. Whatever values are projected within the schema of Eurocentrism, it is clear that without a recourse and adaptation of local realities, the contours of African political landscape will continue to witness the ills of disappointments regardless of how grand the projects of the west may be. In actual fact, many projects of support and sponsorship to the African continent express western notions or paradigms of development have done everything expect to develop the continent. As a matter of fact, it has succeeded in de-emphasizing the necessity of the continent's history in the formation of blueprints of development and progress. One fundamental areas of effect is that of citizenship pride. 
Much of the values of principles promoted through the internet and global satellite technology, and media like CNN, Fox News, CSpan, etc. are western understanding of reality. There has been CNNization and McDonaldization of world realities. This is not to say that all that is western is evil or dangerous. We have all to certain extent benefited from western education and technology. This notwithstanding the values we were taught in our education was western centred values and economies of western nations. Some years back if you go to study philosophy, you are taught many courses in western philosophy but hardly anyone in African philosophy. The continuous propagation of western values, worldviews and paradigms is another form of neocolonialism. If we cannot breakthrough in having an education that is Afrocentric while being open to pluralism of other cultures in the world, we cannot even meet the challenges of globalization.

What we need to do is that we should not be passive recipients of the produces coming from the western world. We must adapt them and fit them into our own ethical and indigenous religious values. We must filter what comes into our African postcolonial situation and ensure that it will build our communities. There is need for a new ethic to combat the profiteering spirit of capitalism and global market. It is in this search for a new ethic to combat globalization in the postcolonial situation that the philosophy of theistic humanism becomes relevant. How can we face or confront the predicament that postcolonial societies face coupled with that of globalization that has worsened the postcolonial situation.

\section{Concluding Reflections}

The paper concludes by affirming that theistic humanism as proposed by Dukor (2010: p. 100) can be a panacea or bulwark to confront the challenges of globalization. It suffices here, as this paper is concluding to note that theistic humanism, which Dukor names as the African Philosophic tradition, has a role to play in re-directing globalization. What globalization needs to overcome its weakness and failures is ethical values and these can be found in African theism. Africans believe in a personal
God the creator of the universe and controller of cosmic destiny. In the cosmic framework human interest is paramount as God has placed man at the center of all things. As Dukor affirms, theism and humanism are compatible in Africa. The African who believes in God also believes that through divine ethical values such as generosity, solidarity, hospitality, compassion, etc the human interest should be nourished and protected. Thus theistic humanism can help to promote and ethical and people friendly globalization.

\section{REFERENCES}

Abecrombie, N., Hill, S., \& Turner, B. (2000). The penguin dictionary of sociology. London: Penguin Books.

Asiegbu, M., \& Agbakoba, J. (2006). Philosophy and praxis in Africa. Ibadan: Hope Publications.

Banjo, L. (2000). IMF, world bank, WTO, the wicked machines of the imperialist. Sunday Tribune, April 23.

Chijioke, O. (2007). Evolving a global mechanism for tracking and reporting corrupt and unethical practices in the public service: The Nigerian experience. Essence, 4, 37.

Daouas, M. (2001). Africa faces challenges of globalization in finance and development. International Monetary Fund, 38, 6-8.

Dukor, M. (2007). Globalization and development. Essence, 4, 5-21.

Dukor, M. (2010). Theistic humanism of African philosophy: The great debate and substance of philosophy. Saarbrucken: LAP LAMBERT Academic Publishing.

Ekiyor, A. (2007). The dynamism of globalization on culture: A case study of Niger Delta in Nigeria. Essence, 4, 37-39.

Hobsbawn, E. (2000). The new century. London: Abacus.

Igwe, O. (2005). Politics and globe dictionary. Aba: Eagle Publisher.

Makumba, M. (2007). Introduction to African philosophy. Nairobi: Paulines Publication Africa.

Omoregbe, J. (1990). Knowing philosophy. Lagos: Joja Educational and Publishing Company.

Oyebola, A. (1982). Black's man dilemma. Ibadan: Board Publications.

Post Colonialism (2009). The free encyclopedia. URL (last checked 4 September 2009). http://www.answer.com/topic/postcolonial

Umo, J. (2007). Economics: An African perspective. Lagos: Millennium Text Publishers Ltd. 